\title{
THE ANALYSIS OF THE EXPORT TAX IMPOSITION ON INDONESIAN COCOA BEANS: IMPACTS ON INDONESIA AND MALAYSIA COCOA PROCESSING EXPORT PERFORMANCE
}

\author{
Hendy Yudyanto \\ Postgraduate Program in Economics, \\ Faculty of Economics and Business, University of Indonesia \\ Depok, Indonesia \\ hyudyanto@yahoo.com
}

\author{
Fithra Faisal Hastiadi \\ Departement of Economics, \\ Faculty of Economics and Business, University of Indonesia \\ Depok, Indonesia \\ fithra_faisal@yahoo.com
}

\begin{abstract}
The purpose of this research is to observe the effects of the export tax tariff imposition on Indonesian cocoa beans against the export of processed cocoa products from Indonesia and Malaysia in the long-term. Research variables used are the export volume of processed cocoa products in Indonesia and Malaysia, price of Indonesian cocoa beans, price of international cocoa beans, average price of processed cocoa exports in 5 competitor countries of Indonesia and Malaysia, volume of processed cocoa imports worldwide and the dummy application of the Indonesian cocoa export tax. In response to the research objectives, the Autoregressive Distributed Lag (ARDL) and the bound testing co-integration methods are used to observe the co-integration of variables researched. Data analyses outcomes indicate that the imposition of export tax on Indonesian cocoa beans significantly affect the increased export volume of the Indonesian processed cocoa in the long-term. Meanwhile, for Malaysia, the imposition of export tax on the Indonesian cocoa beans does not significantly decrease the export volume of Malaysian processed cocoa in the long-term.
\end{abstract}

Key Words: Export Tax, Cocoa Beans, Export, Processed Cocoa, ARDL

Classification JEL : F13; L66;

\section{INTRODUCTION}

One of the aims to impose export tax is to increase the value added of domestic industries. According to Bouet and Laborde (2012), the imposition of export tax will decrease the export volume of raw materials due to higher export prices compared to the international price. The decline of the export supply will lead to an increase in domestic supply, causing a decrease of the raw materials domestically. Thus indirectly, the imposition of the export tax is an incentive provided by the Government to ensure the availability of raw materials for domestic processing industries at a lower price. The low price of raw materials will lead to a decrease in production costs so that the selling price of the downstream products in the export market will be more competitive.
On the other hand, the imposition of export tax on raw materials may also affect the performance of the importing countries of raw materials. Bouet and Laborde (2012) added that the imposition of export tax will decrease the import of the raw materials supply, so that it may affect the increase of raw material prices in the international market. Fung and Korinek (2014) argued that the imposition of export tax on raw materials may lead to a decreased production and profit for downstream industries in importing countries because importing countries have to pay a higher price for imported raw materials from the restricting partner countries; that will increase the production costs for the user industries, and ultimately the final products for the consumers.

The policy of export tax imposition on cocoa beans was issued by the Government through the issuance of the Regulation of the Minister of Finance Number 67 / PMK.011 / 2010 the Stipulation of Export Goods Subject to Export Tax and the Export Tax Tariff. In this regulation, cocoa beans are one of the commodities which export is subject to a particular tariff with a progressive percentage depending on prevailing international prices. The objective of the export tax imposition on cocoa beans is to encourage the downstream of cocoa processing industries. Prior to 2010, most of Indonesian cocoa beans were exported than processed domestically, leading to a shortage of raw materials for domestic industries. This is marked by the low installed capacity utilization of the Indonesian cocoa processing industries in 2009 which was only $42 \%$.

According to ICCO data (2012), in 2009, the Indonesian cocoa beans production was the $3^{\text {rd }}$ largest in the world (15\% share) after the Ivory Coast (34\% share) and Ghana ( $17 \%$ share), namely by 550,000 tons. In the mentioned year, the export of the Indonesian cocoa beans reached 439,305 tons (US\$ 1,087,485), with Malaysia as the largest market share of $41 \%$. Malaysia imports most of the cocoa bean raw materials for their processed cocoa production from Indonesia, due to the very low production of Malaysian cocoa beans at 15,000 tons. Processed cocoa products are divided into 3 (three) types: cocoa paste, cocoa butter and cocoa powder. All product types only use cocoa beans as raw 
materials. In 2009, the use of Indonesian cocoa beans raw materials for the need of cocoa processing industries in Malaysia reached $69 \%$. In this year, Malaysia was the largest exporter of processed cocoa in Asia with an export value of US\$ 797,939, followed by Indonesia in the $2^{\text {nd }}$ position with an export value of US\$295,575. This data indicate that Indonesia is the main producer of cocoa beans in Asia. However, the value added generated is still very low because Indonesia exports more cocoa beans than processed cocoa products. The export value of the Indonesian processed cocoa products is even below Malaysia that precisely uses most of the cocoa beans raw materials from Indonesia for the production of processed cocoa.

The export tax policy on cocoa beans issued by the Government of Indonesia aims to increase the supply of cocoa beans raw materials for domestic use by reducing the export volume of the raw materials. The increased supply of cocoa beans raw materials is expected to grow the Indonesian processed cocoa production; so that it may also improve the competitiveness of processed cocoa products in the world market. Considering that Malaysia is the largest consumer of cocoa beans from Indonesia, the policy of the export tax imposition on cocoa beans may reduce the cocoa beans supply to Malaysia. The decline in the supply of cocoa beans may obstruct the production of Malaysian processed cocoa, so that the processed cocoa industry from Indonesia can capture the market share of the Malaysian processed cocoa in the world.

Therefore, the success of the implementation of the export tax policy on cocoa beans in the long-term is not only observed from the effects of the policy on the export of processed cocoa products from Indonesia, but also it should be considered from the impacts to Malaysia as the main competitor in processed cocoa products in Asia.

\section{LITERATURE REVIEW}

A country applies the export tax policy on products for various purposes. According to Liefert and Wescott (2016), the main reason of the Government to impose export tax tariffs or other export restrictions are for: (1) increasing revenues, (2) increasing profits from export products by using the market power to increase selling prices; (3) increasing competitiveness and also the value added of domestic industries by providing cheaper raw materials so that production costs are lower than competitor countries, and (4) improving domestic food security by rising the product volume at lower prices.

The imposition of export tax on raw materials will decrease the price of raw materials in the domestic market. In addition, export tax may also increase the price of raw materials in the international market, depending on the market share. Bouet and Laborde (2012) grouped the market share of a country into small countries and large countries, and further performed a partial equilibrium analysis to identify the impacts generated from the imposition of export tax. Small countries refer to countries with a small market share, while large countries are countries with large market shares. In this analysis, it is assumed that domestic prices are equal to the international prices; and, domestic demands are lower than the domestic supply. The difference between domestic supply and domestic demand is the quantity exported.

In small countries, the export tax imposition will make the domestic producers prefer to sell their products to the domestic market rather than exporting, because the products are not taxable if sold domestically. The imposition of export tax will lead the domestic prices to decrease. Domestic consumers will benefit from the export tax policy by increasing their consumption at lower prices, due to the decreased export quantities. Increased domestic consumption with lower prices will create a consumer surplus. In addition, the Government will also benefit from the application of export tax, by getting the revenue from the export tax. However, this policy precisely creates disincentives to domestic producers marked by a decreased surplus of producers.

In large countries, the imposition of export duties will lead to the increased world prices. The imposition of export tax on countries with significant market shares in the world will decline the world export supply and increase the world prices. The decline in the export supply will increase domestic consumption, so that domestic prices will decrease. The policy to impose export tax on large countries will create a surplus of both producers and consumers.

In the context of raw materials, the imposition of this policy may affect the value added in the importing countries of the raw materials. According to Murray and Walter (1975), a country may increase the export of downstream products by imposing export tax on raw materials or semi-finished materials; thereby reducing the Effective Rate of Protection (ERP) on the downstream products of the importing country. The imposition of export tax on raw materials in exporting countries will increase production costs of the importing countries' downstream industries, due to the increased prices of raw materials.

A number of previous researches related to the policy impacts of the cocoa bean export tax towards the processed cocoa exports were done several times, such as the research by Suryana et.al (2014) that analyzed the impacts of the export tax imposition on cocoa beans towards the volume of processed cocoa exports by applying the gravity model with panel data. Research outcomes indicate that the export tax policy has a significant impact on the increase of cocoa butter export volume; however it does not significantly impact to the increased export volume of cocoa powder. Further, Gumay (2014) performed a research on the impacts of the cocoa beans export tax enforcement on the competitiveness of Indonesian processed cocoa products by using the method of the Ordinary Least Square and data time series. Research outcomes indicate that the policy of the cocoa beans export tax significantly increase the competitiveness of the Indonesian processed cocoa products in the international market. 


\section{METHODS}

The empirical model used to estimate the demand function in Indonesian and Malaysian exports follows the "imperfect substitutes" model established by Goldstein and Khan (1985). The function of the export demand is as follows:

$X^{d}=x\left(P X_{g}, P X_{c}, Y^{f}, K\right), \quad f_{1}<0, f_{2}>0, f_{3}>0, f 4>$ 0 (2)

whereas $X^{d}=$ Quantity of domestic products exported to international markets, $P X_{g}=$ prices of domestic products, $P X_{C}=$ price of competitor products in the international market, $Y^{f}=$ real foreign revenue, $\mathrm{K}=$ capital stock

Further, the long-term model of the Indonesian processed cocoa exports determinant used in this research is as follows:

$$
\begin{aligned}
\ln X I N D_{t}= & \beta_{0}+\beta_{1} \ln D P B_{t}+\beta_{2} P X C_{t}+\beta_{3} \ln W M P_{t}+ \\
& \beta_{4} B K_{t}+\varepsilon_{t}
\end{aligned}
$$

where $\beta_{1}<0, \beta_{2}>0, \beta_{3}>0, \beta_{4}>0$

Description:

$\begin{aligned} \ln \mathrm{XIND}= & \begin{array}{l}\text { Natural logarithm of export volume of } \\ \text { processed cocoa products in Indonesia in } \\ \text { month-t (ton) }\end{array} \\ \mathrm{LnDPB}= & \begin{array}{l}\text { Natural logarithm of the Indonesian cocoa } \\ \text { beans price in month-t }(\mathrm{Rp} / \mathrm{kg})\end{array} \\ \mathrm{PXC} & \begin{array}{l}\text { Average export price of processed cocoa in } \\ \text { the } 5 \text { competitor countries of Indonesia in } \\ \text { month-t (US } \$ \mathrm{~kg})\end{array} \\ \mathrm{lnWMP}= & \begin{array}{l}\text { Natural logarithm of the volume of processed } \\ \text { cocoa imports in the world in month-t (ton) }\end{array} \\ \mathrm{BK} & \begin{array}{l}\text { Dummy application of export tax of } \\ \text { Indonesia cocoa beans, valued } 1 \text { if imposed } \\ \text { with the export tax tariff in the related month, } \\ \text { value } 0 \text { if in the related month the export tax } \\ \text { tariff is not implemented } \\ \text { error term in month-t }\end{array}\end{aligned}$

The price of domestic cocoa beans is used as an independent variable on the model of Indonesian processed cocoa exports as proxy of the Indonesian processed cocoa price. The average of processed cocoa prices in 5 Indonesian competitor countries is used as an independent variable that is expected to be positively related to the Indonesian processed cocoa exports. The 5 competing countries selected are the United States, the Netherlands, Germany, Malaysia and France. The volume of processed cocoa imports in the world is used as proxy of foreign real revenues. To identify the longterm relationships between the Indonesian processed cocoa exports and the price of domestic cocoa beans, the average price of competitor processed cocoa, the import volume of the world's processed cocoa and the export tax policy on the Indonesian cocoa beans, the following ARDL equation is established:

$$
\begin{array}{r}
\Delta \ln X I N D_{t}=\alpha+\beta_{0}+\beta_{1} \ln X I N D_{t-1}+\beta_{2} \ln D P B_{t-1}+ \\
\beta_{3} P X C_{t-1}+\beta_{4} \ln W M P_{t}+\beta_{5} B K_{t-1}+
\end{array}
$$

$$
\begin{aligned}
& \sum_{i=1}^{p} \beta_{6 i} \Delta \ln X I N D_{t-i}+ \\
& \sum_{j=1}^{q} \beta_{7 j} \Delta \ln D P B_{t-j}+ \\
& \sum_{k=1}^{q} \beta_{8 k} \Delta P X C_{t-k}+ \\
& \sum_{m=1}^{q} \beta_{9 m} \Delta \ln W M P_{t-m}+ \\
& \sum_{n=1}^{q} \beta_{10 n} \Delta B K_{t-n}+\epsilon_{t}
\end{aligned}
$$

Coefficient $\beta_{1}, \beta_{2}, \beta_{3}, \beta_{4}$ and $\beta_{5}$ illustrate the coefficient of a long-term relationship.

Further, the ECM equation used in this research is as follows:

$$
\begin{aligned}
& \Delta \ln X I N D_{t}=\alpha+\sum_{i=1}^{p} \theta_{1 i} \Delta \ln X I N D_{t-i}+\sum_{j=1}^{q} \varphi_{1 j} \Delta \ln D P B_{t-j}+ \\
& \sum_{j=1}^{q} \varphi_{2 j} \Delta P X C_{t-j}+\sum_{j=1}^{q} \varphi_{3 j} \Delta \operatorname{lnWMP_{t-j}+} \\
& \sum_{j=1}^{q} \varphi_{3 j} \Delta B K_{t-j}+\gamma E C T_{t-1}+\epsilon_{t}
\end{aligned}
$$

Whereas $\theta$ and $\varphi$ are short-term coefficients and $\gamma$ is the speed of adjustment.

This research also establishes the determinant model of the Malaysian processed cocoa exports. The proxy used for the variable of domestic processed cocoa prices is different from the proxy used in the model of the Indonesian processed cocoa exports. Differences in the proxy used are due to the different characteristics of raw materials used in the cocoa processing industries in Indonesia and Malaysia.

Unlike Indonesia that uses most of the domestic cocoa beans as raw material, Malaysia mostly uses imported cocoa beans as raw material for the processed cocoa. The determinant model of Malaysian processed cocoa exports is as follows:

$$
\begin{aligned}
\ln X M A S_{t}= & \gamma_{0}+\gamma_{1} \ln W P B_{t}+\gamma_{2} P X C_{t}+\gamma_{3} \ln W M P_{t}+ \\
& \gamma_{4} B K_{t}+\varepsilon_{t} \\
\text { where } \gamma_{1}< & 0, \gamma_{2}>0, \gamma_{3}>0, \gamma_{4}<0
\end{aligned}
$$

Description :

$\operatorname{lnXMAS}=$ Natural logarithm of export volume of processed cocoa products in Malaysia in month-t (ton)

$\operatorname{lnWPB}=$ Natural logarithm of international cocoa beans prices in month-t (US\$/ton)

PXC $=$ Average export price of processed cocoa in 5 Malaysia competitor countries in month-t (US\$/kg)

lnWMP $=$ Natural logarithm of import volume of processed cocoa in the world in month-t (ton)

BK = Dummy application of Indonesian export tax of cocoa beans by Indonesia, value 1 if in the related month the export tax tariff is imposed, value 0 if in the related month the export tax tariff is not imposed

$\varepsilon_{t} \quad=\quad$ error term in month-t

The international cocoa beans prices are used as independent variables of Malaysia's processed cocoa export model. The variable of average processed cocoa prices in this model is taken from Malaysia's competitor countries which 
are the United States, the Netherlands, Germany, Indonesia and France. The proxy of real foreign revenues used in the model of the Malaysian processed cocoa exports is the import value of the world processed cocoa.

To indicate the long-term relationships between Malaysian processed cocoa exports and the international cocoa beans prices, the average price of processed cocoa competitors, the import volume of the world processed cocoa and the export tax policy on Indonesian cocoa beans, the following ARDL equation is established:

$$
\begin{aligned}
\Delta \ln X M A S_{t}= & \alpha+\beta_{0}+\beta_{1} \ln X M A S_{t-1}+\beta_{2} \ln W P B_{t-1}+ \\
& \beta_{3} P X C_{t-1}+\beta_{4} \ln W M P_{t}+\beta_{5} B K_{t-1}+ \\
& \sum_{i=1}^{p} \beta_{6 i} \Delta \ln X M A S_{t-i}+ \\
& \sum_{j=1}^{q} \beta_{7 j} \Delta \ln W P B_{t-j}+\sum_{k=1}^{q} \beta_{8 k} \Delta P X C_{t-k}+ \\
& \sum_{m=1}^{q} \beta_{9 m} \Delta \ln W M P_{t-m}+ \\
& \sum_{n=1}^{q} \beta_{10 n} \Delta B K_{t-n}+\epsilon_{t}
\end{aligned}
$$

Coefficient $\beta_{1}, \beta_{2}, \beta_{3}, \beta_{4}$ and $\beta_{5}$ illustrate the coefficient of the long-term relationship

The ECM equation for the determinant model of Malaysian processed cocoa export is as follows:

$\Delta \ln X M A S_{t}=\alpha+\sum_{i=1}^{p} \theta_{1 i} \Delta \ln X M A S_{t-i}+\sum_{j=1}^{q} \varphi_{1 j} \Delta L N W P B_{t-j}$ $\sum_{j=1}^{q} \varphi_{2 j} \Delta P X C_{t-j}+\sum_{j=1}^{q} \varphi_{3 j} \Delta \operatorname{lnWMP} P_{t-j}+$

$\sum_{j=1}^{q} \varphi_{3 j} \Delta B K_{t-j}+\gamma E C T_{t-1}+\epsilon_{t}$

Whereas $\theta$ and $\varphi$ are the short-term coefficients and $\gamma$ is the speed of adjustment.

This research uses secondary data in the form of monthly data from 2006 to 2015. The export volume of processed cocoa products is the addition of the export volume of cocoa paste products (HS. 1803), cocoa butter (HS. 1804) and cocoa powder (HS. 1805). Data of the processed cocoa export volume, average price of competitor countries' processed cocoa and import volume of the world processed cocoa are sourced from trademap.org. The Data of domestic cocoa beans prices are sourced from bappepti.go.id, while the international cocoa beans prices are obtained from icco.org. The export tax data of Indonesian cocoa beans are obtained from kemendag.go.id. The Error Correction Models (ECM) is applied as the estimation method in this research, by using the Autoregressive Distributed Lag (ARDL) method developed by Pesaran et.al (2001). The Eviews 9 software is used to process the data in this research.

\section{RESULT AND DISCUSSION}

\subsection{Research Outcomes}

\subsubsection{Estimation Outcome Models of Indonesian Processed Cocoa Exports}

Table. 1. Estimation Outcomes of the ECM Equation

\begin{tabular}{|c|c|c|}
\hline Variable & Coefficient & Prob. \\
\hline D(LN_XIND(-1)) & -0.329083 & 0.0001 \\
\hline D(LN_DPB) & -0.018190 & 0.8190 \\
\hline D(PXC) & 0.254758 & 0.1131 \\
\hline D(LN_WMP) & 0.369232 & $0.0389^{*}$ \\
\hline D(BK) & 0.034949 & 0.5746 \\
\hline CointEq(-1) & -0.236492 & $0.0001^{*}$ \\
\hline
\end{tabular}

Significant at level 10\%:*

Table. 2. Estimation Outcomes of the Co-integration Equation

\begin{tabular}{|c|c|c|}
\hline Variable & Coefficient & Prob. \\
\hline LN_DPB & -0.076918 & 0.8211 \\
\hline PXC & -0.391263 & $0.0970^{*}$ \\
\hline LN_WMP & 1.561287 & $0.0187^{*}$ \\
\hline BK & 0.838704 & $0.0036^{*}$ \\
\hline C & -7.500364 & 0.3240 \\
\hline
\end{tabular}

Significant at level 10\%:*

\subsubsection{Estimation Outcome Models of the Malaysian Processed Cocoa Export}

Table. 3. Estimation Outcomes of the ECM Equation

\begin{tabular}{|c|c|c|}
\hline Variabel & Koefisien & Prob. \\
\hline D(LN_WPB $)$ & -0.130302 & 0.2217 \\
\hline D(PXC) & 0.087323 & 0.1034 \\
\hline D(LN_WMP) & 0.077997 & 0.4028 \\
\hline D(BK) & -0.013418 & 0.6914 \\
\hline CointEq(-1) & -0.511425 & $0.0000^{*}$ \\
\hline
\end{tabular}

Significant at level 10\%: *

Table. 4. Estimation Outcomes of the Co-integration Equation

\begin{tabular}{|c|c|c|}
\hline Variabel & Koefisien & Prob. \\
\hline LN_WPB & -0.254782 & 0.2104 \\
\hline PXC & 0.170744 & $0.0870^{*}$ \\
\hline LN_WMP & 0.152509 & 0.4048 \\
\hline BK & -0.026237 & 0.6909 \\
\hline C & 9.454903 & 0.0005 \\
\hline
\end{tabular}

Significant at level 10\%: *

\subsection{Discussion}

The Estimation outcomes of the determinant model of the Indonesian processed cocoa exports as presented in Table 2. indicate that in the long-term, the variables of export tax on cocoa beans, import volume of the world processed cocoa, and the average of processed cocoa prices of Indonesia's competitor countries significantly affect the export volume of the Indonesian processed cocoa. The policy of export tax imposition on cocoa beans in the long-term will significantly increase the export volume of the Indonesian processed cocoa. The increased export volume that is affected by the increased export tax on the Indonesian cocoa beans already conforms to 
the hypothesis presented in this research. The export tax imposition policy on cocoa beans leads to a decrease in Indonesia's cocoa beans export. The declined export will cause an abundance of domestic cocoa bean raw materials that encourages investments in the national cocoa processing industries. The increasing cocoa processing industries will grow the processed cocoa production that may raise the Indonesian processed cocoa export value. According to Piermartini (2004), domestic processing industries will benefit from the export tax imposition on the input of the decreased raw material prices; so that it may increase competitiveness and expand the international market share.

From the ECM equation estimation outcomes in Table.2, the coefficient value of ECT(-1)/CointEq(-1) is -0.23 which is significant. This means that $23 \%$ disequilibrium is occurring between the $\ln$ XIND and $\operatorname{lnDPB}, \mathrm{PXC}$, InWMP, while the $\mathrm{BK}$ will be re-corrected within one period (one month). The negative coefficient mark indicates that there is a corrective mechanism for the long-term balance.

The determinant model on estimation outcomes of Malaysian processed cocoa export in the long-term as presented in Table. 3 indicates that independent variables that significantly affect the Malaysian export volume of processed cocoa are only the average variables of the processed cocoa prices in the Malaysia's competitor countries. The dummy variables on the policy of the export tax imposition on the Indonesian cocoa beans have a negative effect; however are not significant against the export volume of the Malaysian processed cocoa. Even though the import of cocoa beans from Indonesia will decrease after the export tax is applied to the Indonesian cocoa beans, this does not affect the Malaysian export of processed cocoa. The policy of applying the export tax on Indonesian cocoa beans is expected not to cause an increase in the international cocoa bean prices. According to Salim and Ali (1974), increased prices on products subject to export tax in the world may occur if the export volume of the taxed products declines and no other country fills the declining export volume with similar products. The decreased supply of the Indonesian cocoa beans is anticipated by Malaysia by importing the cocoa beans from the Ivory Coast and Ghana; so that the supply of cocoa beans as raw materials in the Malaysian processed cocoa industries is still maintained.

From the estimation outcomes of the ECM equation against the model of the Malaysian processed cocoa exports, a coefficient value of ECT $(-1) / C$ ointEq( $(-1)$ is obtained of -0.51 and significant. This means that $51 \%$ disequilibrium that occurs between $\ln X \mathrm{MAS}$ and $\ln \mathrm{WPB}, \mathrm{PXC}$, lnWMP and BK will be re-corrected in one period (one month). The negative coefficient mark indicates that there will be a correction mechanism on the long-term balance.

\section{CONCLUSIONS}

The Data analyses outcomes indicate that the imposition of the export tax on the Indonesian cocoa beans significantly affects the increased value of the Indonesian processed cocoa exports in the long-term. Meanwhile, for
Malaysia, the imposition of the export tax on the Indonesian cocoa beans does not significantly affect the decreased value of the Malaysian processed cocoa exports in the long-term.

The export tax imposition on the Indonesian cocoa beans in the long-term will increase the value of Indonesian processed cocoa exports. As the tariff imposition policy will significantly impact in the long-term, it is best to continue the implementation of the policy. The policy does not significantly decrease the Malaysia's processed cocoa exports. In order to be able to compete with the Malaysian processed cocoa products in the world market, the Indonesian processed cocoa industries need to continuously improve the quantity and quality of the products.

\section{REFERENCES}

Athanasoglu, P. P., \& Bardaka, I. C. (2009). New Trade Theory, Non Price Competitiveness and Export Performance. Economic Modelling, 217-288.

Bouët, A., \& Laborde, D. (2012). Food Crisis and Export Taxation: The Cost of Non-Cooperative Trade Policies. Review of World Economics / Weltwirtschaftliches Archiv, 148(1), 209-233.

Fung, K. C., \& Korinek, J. (2014). Economics of Export Restrictions as Applied to Industrial Raw Materials. OECD Trade Policy Papers (hal. 63-92). Paris: http://www.oecd.org/trade/benefitlib/exportrestrictions-raw-materials-2014.pdf.

Goldstein, M. and Khan, M.S. (1985) Income and Price Effects in Foreign Trade. In: Jones, R.W. and Kenen, P.B., Eds., Handbook of International Economics, Elsevier Science Publications, New York, Vol. II, 1041-1105.

Gumay, H. S. (2014). Analisis dampak penerapan kebijakan bea keluar Biji Kakao terhadap kinerja industri pengolahan Kakao dan daya saing produk olahan Kakao Indonesia. Jakarta: MPKP Fakultas Ekonomi dan Bisnis UI Tesis.

Liefert, W. M., \& Westcott, P. C. (2016). Modifying Agricultural Export Taxes to Make Them Less Market Distorting. Food Policy, 65-77.

Murray, T., \& Walter, I. (1975). The Impact of Export Subsidy and Tax Programs on Effective Protection. Weltwirtschaftliches Archiv, 439-453.

Pesaran, M. H., Shin, Y., \& Smith, R. J. (2001). Bounds Testing Approaches to the Analysis of Level Relationships. Journal of Applied Econometrics, 16(3), 289-326.

Piermartini, R. (2004). The Role of Export Taxes in the Field of Primary Commodities. WTO Discussion Paper. 
Salim, G., \& Ali, R. (1974). Export Taxes and Fiscal Policy in Developing Countries With Spesial Reference to the Sudan. University of Khartoum, 55, 111-112.

Suryana, A. T., Fariyanti, A., \& Rifin, A. (2014). Analisis Perdagangan Kakao Indonesia di Pasar Internasional. TIDP, 1(1), 29-40. 